\title{
Evaluating the Social Sustainability Criteria of Supply Chain Management in Manufacturing Industries: A Role of BWM in MCDM
}

\author{
Ocena kryteriów zrównoważoności społecznej \\ w zarządzaniu łańcuchem dostaw w przemyśle wytwórczym: \\ rola BWM w MCDM
}

\author{
Maryam Khokhar*, Yumei Hou**, Muhammad Asim Rafique ${ }^{\star \star \star}$, \\ Wasim lqbal ${ }^{\star \star \star *}$
}

\author{
School of Economics and Management Yanshan University, China \\ E-mails: *maryamkhokhar@stumail.ysu.edu.cn,****wasimiqbal01@yahoo.com \\ Corresponding authors:**hym@ysu.edu.cn,***asimchoudhary786@gmail.com
}

\begin{abstract}
Supply chain management firms are gradually pressurized to incorporate social sustainability practices to address social issues. Though, the researchers emphasized on different dimensions of sustainable supply chain management (SSCM), i.e., social, environmental and economic but fewer considered the social aspect of sustainability. The purpose of this research is to take into account the social dimension of sustainability into manufacturing industries. The social dimension of sustainability as compared to other sustainable, has severe adverse impact across supply chains. In order to demonstrate the applicability and efficiency of social sustainability in supply chain management, a sample of 53 practitioners of Pakistani manufacturing companies has been selected to prioritize and evaluate the SCSS criteria by applying a decision-making multi-criteria method called the best worst method (BWM). The criteria of the study are ranked according to their average weight achieved through BWM. The criterion employment practices has been chosen as the most significant criterion while cultural values criterion is considered as least important. The results of this study are helpful for industry managers, practitioners and decision-makers to take the decisions for the implementation of social criteria to enhance the social sustainability that lead to sustainable development.
\end{abstract}

Key words: Supply Chain Social sustainability (SCSS); Best Worst Method (BWM); Multi-Criteria Decisionmaking Method (MCDM), Manufacturing Industries

\section{Streszczenie}

Firmy zarządzajace łańcuchem dostaw sa poddawane presji, aby wprowadzić praktyki zrównoważonego rozwoju społecznego w celu rozwiązania problemów społecznych. Chociaż naukowcy zwracają uwagę na różne wymiary zrównoważonego zarządzania łańcuchem dostaw (SSCM), tj. społeczny, środowiskowy i ekonomiczny, jednak należy zauważyć, że w najmniejszym stopniu dyskutowane są aspekty społeczne. Celem tych badań jest uwzględnienie społecznego wymiaru zrównoważonego rozwoju w przemyśle wytwórczym. Społeczny wymiar zrównoważoności, w porównaniu z innymi, ma poważny negatywny wpływ na łańcuchy dostaw. W celu wykazania możliwości zastosowania i efektywności zrównoważoności społecznej w zarządzaniu łańcuchem dostaw, wybrano próbę 53 praktyków z pakistańskich firm produkcyjnych w celu ustalenia priorytetów i oceny kryteriów SCSS poprzez zastosowanie wielokryterialnej metody decyzyjnej zwanej najlepszą/najgorszą metodą (BWM). Kryteria badania są uszeregowane według ich średniej wagi osiągniętej w BWM. Kryterium dotyczące zatrudnienia zostało wybrane jako najistotniejsze, natomiast kryterium wartości kulturowych jest uważane za najmniej ważne. Wyniki tego badania są pomocne dla menedżerów branży, praktyków i decydentów w podejmowaniu decyzji dotyczących wdrażania kryteriów społecznych w celu zwiększenia zrównoważości społecznej, która prowadzi do zrównoważonego rozwoju.

Słowa kluczowe: łańcuch dostaw społecznej zrównoważoności (SCSS), najlepsza/najgorsza metoda (BWM), metoda podejmowania decyzji na podstawie wielu kryteriów, przemysł wytwórczy 


\section{Introduction}

Regardless of the increasing stakeholder attentiveness on social sustainability matters, little is identified about what influences adaptation of practices of social sustainability in supply chain management and the advantages cultivated from such efforts. The foremost damage of the natural environment and the life of humans was done due to industrialization (Ogasawara and Yumitori, 2019). Therefore, for the organizations, it is a dire need to work collectively in sustainable supply chains (Galal and Moneim, 2016; Shibin, Gunasekaran and Dubey, 2017), keeping into consideration three various criteria of sustainability; environmental criteria, economic criteria as well as social criteria (Interlenghi et. al., 2017). Due to the increasing knowledge of social sustainability, developing community's responsiveness and policies of the government, the sustainable performance is progressively becoming a crucial organizational strategy (Hale, Legun, Campbell and Carolan, 2019). Literature to a much lesser extent has focused on social sustainability, which is unfortunate since not only all three measurements are genuinely needed to construct a sustainable business, but practices of social sustainability provide assistance to improve the other facets of sustainability.

A massive literature on sustainability is available, that covers all three dimensions, but researchers mainly emphasized on environment and economic sustainability. Yet, empirical studies on the specific factors and their outcomes in social sustainability implementation from an emerging economy are still rare. Scholar acknowledges the need for the reviews on social sustainability in developing economies, to take a broader view of the findings for theory and practices. To precise the disparity, this paper proposes, a unified assessment model developed to explore social sustainability in the vicinity of Pakistan's manufacturing industry. In this investigation, multi-criteria decision-making method (MCDM), the best worst method (BWM) was used to prioritize and evaluate the social sustainability (Mi, Tang, Liao, Shen and Lev 2019; Rezaei, 2016). We chose the Pakistan' supply chain of manufacturing sector due to the following two main reasons. Firstly, Pakistan's economy in large scale relies on its manufacturing sector which is the 2nd largest sector contributing to GDP after agriculture sector; meanwhile, this segment looks severe challenges, extending from workers' rights related to lousy employment practices, strike movements due to the work protection and health motives. Secondly, the manufacturing sector needs certain type of best practices described to social sustainability of manufacturing sector's supply chain to guide the existing and new entering companies in decision making relating to sustainability to reconstruct the negative social reputation. For all that, the triple-dimension (social, economic and environmental) to have sustainability in supply chain management (SSCM) should be considered together, however, this study is exerting its focus on the social sustainability dimension for better understanding. Therefore, the outcomes of this research could be constructive as input for widespread management decisions in the supply chain. So, the purpose of this study is to determine the essential social criteria with the motive to propose a model to assess social sustainability in manufacturing industry's supply chain. Additionally, with the help of this study, the practical and managerial implications have been determined to keep into considering the developing economies and their regulatory compliance that influences on adoption of social sustainability.

\section{Literature review}

\subsection{Sustainability in Supply Chain Management (SSCM)}

Firms are gradually considered responsible for their environmental, social, and economic consequences due to their internal operations and by their contractors' operations over the past two decades. Sustainability in supply chain management (SSCM), which is concerned with integrating environmental, social and economic goals of firm's supply chain practices, has emerged as an approach to the sustainable outcomes in their supply chains (Yawar and Seuring, 2017). Managing the sustainability, however, continues to be challenging in global supply chain management system (Epstein, 2018).

Sustainability supply chain management (SSCM) is a set of methodologies and practices for achieving and managing a real harmonization between organizations (cross-organizational) and within the organizations (cross-functional) in supply chains. The main objective of sustainable supply chain management is to enhance customer service, profit generation, asset utilization and cost reduction (Huo, Gu and Wang, 2019); processes, information and resources that may lead to losing their direct control (Dias and Ierapetritou, 2017) due to the involvement of multiple decision makers. In other words, organizations in line with supply chains, can make their supply chain operations more sustainable by integrating their operations and work together (Jia, Gong and Brown, 2018).

Sustainable supply chain management may also be pronounced as the managing and controlling the funds, information resources operations and other activities with the aim to increase the profitability as well as the well-being of their employees, customers and society overall. At the same time, it also reduces any negative environmental influence (Das 2018; Shi et al. 2017).

Organizations' prospective societal and environmental impacts of supply chain processes are together tricky and difficult to cope (Wang, Singgih, Wang and Rit, 2019). Therefore, SSCM minimizes 
Table 1. Previous Studies Available on Sustainability

\begin{tabular}{|c|c|c|c|c|c|}
\hline $\begin{array}{l}\text { Environmental } \\
\text { Sustainability }\end{array}$ & $\begin{array}{l}\text { Economic } \\
\text { Sustainability }\end{array}$ & $\begin{array}{l}\text { Social Sus- } \\
\text { tainability }\end{array}$ & $\begin{array}{l}\text { Environmental and Eco- } \\
\text { nomic Sustainability }\end{array}$ & $\begin{array}{l}\text { Social and Environ- } \\
\text { mental Sustainability }\end{array}$ & $\begin{array}{l}\text { Social and Eco- } \\
\text { nomic Sustainability }\end{array}$ \\
\hline 15 & 0 & 2 & 85 & 2 & 0 \\
\hline
\end{tabular}

the negative influence of supply chain operations and advances value of firm/ efficiency related to economic, social and environment issues that ultimately leads to sustainable development which has substantial impact on company's competitiveness. The main motive is to construct the essential abilities to strenghten the organizations' sustainable competitiveness and to strive for collective advantages of supply chain (Govindan, 2018; Manavalan and Jayakrishna, 2019).

The SSCM framework of decision making emphases on the five strategic areas that are material selection, designing of product, developing processes, delivery of finished products to consumers, and the managing the disposial of products at the end life the product (Kornuta et al. 2019; Rachih, Mhada and Chiheb, 2019). Although they developed the sustainability framework, it did not comprise of vibrant criteria containing the social dimension because, without this dimension, any action regarding sustainability is sure to be weak and unable to deal with social influence. The studies by Ahi, Searcy, and Jaber (2018) suggested the resource dependence theory, corporation resource-based view, and population ecology to establish an SSCM model considering essential supportive factors which are necessary for the employment of SSCM practices. The researchers investigated the association between economic, social and environmental performance to obtain economic capability in long-run within the context of SSCM. Still, the social sustainability criteria were addressed to a lesser extent when the framework was developed (Soundararajan and Brammer, 2018). Conversely, they did not draw abundant emphasis on social sustainability and its influence on organizations. Several studies suggested a framework for the management of quality, safety and sustainability in food supply chains, however, their studies did not comprise the dimensions of social sustainability (Manzini and Accorsi 2013; Nawaz, Linke and Koç, 2019).

Thorough literature review revealed that a worthful studies are available on corporate sustainability and organizational sustainability overall, but only a few studies focused only on the specific social sustainability dimension which needs further to be study especially in developing nations. So, the main focus of this study is to shed light on the organizational sustainability with specific emphasis on supply chain social sustainability.

Conforming to Table 1, very few studies have included social dimensions of sustainability. In principle, there are only two papers that has examined the social sustainability (Badri Ahmadi, Kusi-Sarpong and Rezaei, 2017) and (Hutchins and Sutherland,
2008), while only two studies focused on environmental and social sustainability (Tost et. al., 2018).

\subsection{Supply Chain Social Sustainability Criteria (SCSS)}

Additionally, to the environmental and economic sustainability of the organizational processes, social sustainability criteria should also be considered when firms are aiming and attaining the sustainable development and long-term survival. Worker's health, human rights, equity, diversity, and other social \& security-related issues are imperative components when it moves towards sustainability of manufacturing sector and should be considered when assessing, for example, their vendors (Sutherland et al. 2016). Other scientists practice the same narrative for discoursing social issues in supply chain (Martínez-Blanco et al. 2014). It is challenging to determine widespread social sustainability measures and its dimensions due to absence of conceptual clarity, specifically in the operations and manufacturing segment in developing countries. So it's cleared that the managers of the supply chain are not thoughtful enough about the social concerns implied and how they can be analyzed and accomplished (Gopal and Thakkar, 2016; Spence and Rinaldi, 2014).

Till now, fewer studies have assimilated the social sustainability dimension in their SSCM framework while studying sustainability management practices. In most of the cases, the companies have less focused in social initiatives while working on overall corporate sustainability (Ahmadi, Kusi-Sarpong and Rezaei 2017). These endeavors do not shape the competencies and resources required to accomplish comprehensively and systematically the societal influence of supply chain in the direction of cultivating the social measures. Few studies which have assumed the preliminary step in ascertaining and scrutinizing some valuable criteria and dimensions related to social sustainability remained unsuccessful. Therefore, this study aims to assimilate the social sustainability of supply chain into a cohesive and more inclusive framework.

Even though several models by Kumar and Anbanandam (2019), Sierra, Yepes and Pellicer (2018), Ramezankhani, Torabi and Vahidi (2018); Hussain, Ajmal, Gunasekaran and Khan (2018), Arcese, Lucchetti and Massa (2017), Rajak and Vinodh (2015), Azadnia et al. (2015), Ciliberti et al. (2008) that have endeavored to study the dimension of social sustainability, but these efforts are not so helpful that they could support the organizations to shape the proficiencies and resources they need to cope with the social effect of their maneuvers systematically 
Table 2. Identification of Social Criteria in the Context of SSCM of Manufacturing Sector Conforming to Literature.

\begin{tabular}{|l|l|l|}
\hline$\#$ & Criterion Focus & Source \\
\hline 1 & Aesthetics and degradation of community & Pan 2008; Balali et al. 2014 \\
\hline 2 & Business practices & Azevedo, Carvalho, Duarte and Cruz-Machado,2012 \\
\hline 3 & Condition of work & Maxwell and van der Vorst 2003 \\
\hline 4 & Community Education \& training influence & Axelsson et al. 2013; Shaiu et al. 2015 \\
\hline 5 & Cultural values & Shen et al. 2011; Jeong et al. 2014 \\
\hline 6 & Customer problems & Martínez-Jurado and Moyano-Fuentes, 2014 \\
\hline 7 & Economy and local development & Kucukvar et al. 2014; Resendez et al. 2014; Koo et al. 2009; \\
\hline 8 & Economy and regional development & Labuschagne and Brent 2008; \\
\hline 9 & Employment practices & Ciliberti, Pontrandolfo and Scozzi 2008 \\
\hline 10 & Enforcement & Sigala 2008 \\
\hline 11 & Health and safety at work & Closs, Speier and Meacham 2011 \\
\hline 12 & Influence of contractual stakeholders & Oruezabala and Rico 2012 \\
\hline 13 & Information disclosure & O'Rourke 2014 \\
\hline 14 & Local communities influence & Font et. al. 2008 \\
\hline 15 & Mobility and accessibility & Shang et al. 2004; Umer et al. 2016; Shaiu et al. 2015 \\
\hline 16 & Occupational Health and Safety management & Kleindorfer et. al. 2009 \\
\hline 17 & Pystem & \\
\hline 18 & Public opinion & Dasgupta and Edwin 2005; Zavadskas et al. 2015 \\
\hline 19 & Research, development and innovation & Labuschagne and Brent 2008; Karami et al. 2017 \\
\hline 20 & Respect for the policy & Labuschagne and Brent 2006, \\
\hline 21 & Safety of the environmental & Nishat Faisal 2010 \\
\hline 22 & The cultural criterion & Shen et al. 2011 \\
\hline 23 & Stakeholders Right & Axelsson et al. 2013; Shen et al. 2011; Jeong et al. 2014 \\
\hline 24 & Urbanization services & Wolf 2014 \\
\hline & & $\begin{array}{l}\text { Gilmour et al. 2011; Delgado and Romero 2016; Labuschagne and } \\
\text { Brent 2006 }\end{array}$ \\
\hline
\end{tabular}

and comprehensively. Since a more widespread and integrated model, with the purpose to facilitate the manufacturing sector, integrating social sustainability in supply chains is not available presently. In this study, 24 criteria of social sustainability were pointed out based on comprehensive literature review (see table 2).

\section{Methodology}

Table 2 depicting that social sustainability is a concept of multi-criteria, so, various criterion are mentioned in this table. Therefore, to measure the applicability of several criteria, we use Multi-Criteria Decision-Making Method (MCDM). There are numerous MCDM methods available. For more details, among others, we endorse the technique developed by Greco et al. (2005) and Triantaphyllou (2000). MCDM methods have been put on in numerous felids together with sustainable management in supply chain. For detailed information, we also endorse Seuring (2014). In this research the researchers use the Best Worst Method (BWM). It is a unique method which has not been used in this capacity before more than once, and that has inimitable improvement for this paper. The description of this method is explained in following section.

\subsection{Best Worst Method}

The best worst method (BWM) has been established to resolve MCDM issues by Rezaei $(2015,2016)$ that consist of pairwise assessment. BWM has two main benefits when compared to other MCDM methods. First, it requires less number of pairwise contrast data matched to a full pairwise matrix and second, the outcomes produced by BWM are more reliable than the results produced by other MCDM method which is also the principal motive for using Best Worst Method BWM in this research. This method has already been used before in several studies in many studies conducted by Kusi-Sarpong, Gupta and Sarkis (2019), Schätter, Hansen, Wiens and Schultmann (2019), Aboutorab, Saberi, Asadabadi, Hussain and Chang (2018), Rezaei, Hemmes and Tavasszy (2017), Salimi and Rezaei (2016) to solve various real-world issues.

The BWM is structured as follows:

Step 1. First and foremost choose the set of decisionmaking criteria. The set of criteria is selected as follows $\{\mathrm{c} 1, \mathrm{c} 2, \mathrm{c} 3 \ldots . ., \mathrm{cn}\}$.

Step 2. The best criteria mean the most significant, most desired, and the worst criteria indicate the least significant, least desired. In these criteria, the decision-maker determines the best and worst criteria.

Step 3. The fondness of essential criteria, among others is decided based on a score between 1-9. Score 1 means identical preference between the best and worst criteria whereas rating 9 indicates the highest preference of the most significant criteria over the other. The outcome of this phase is the vector of Best-to-Others (BO) shown as $\mathrm{A}_{\mathrm{B}}=\left(a_{B 1}, a_{B 2}\right.$, $\left.a_{B 3}, \ldots, a_{B n},\right)$. Wherever $a_{B j}$, designates the best criteria preference of " $B$ " over "J" criteria and it can be assumed that $a_{B B}=1$. 
Step 4. The liking of all criteria over the worst criteria is known based on a score between 1 and 9. The outcome of this phase is the vector of others to worst (OW), which would be:

$A_{w,}=\left(a_{1 w}, a_{2 w}, a_{3 w}, \ldots \ldots, a_{n w}\right) \mathrm{T}$ where $a_{j w}$, shows the fondness of the " $\mathrm{j}$ " criterion over the worst criterion W. It also be presumed that $a_{w w}=1$.

Step 5. The optimum weight $\left(w_{1}^{*}, w_{2}^{*}, w_{3}^{*}, \ldots \ldots, w_{n}^{*}\right)$ computed. The optimum weights of the criteria will fulfill the following prerequisites: for every pair of $w_{B} / w_{j}$ and $w_{j} / w_{w}$, the best condition is where $w_{B} / w_{j}$ $=a_{B j}$. Consequently, to catch as close as possible to the perfect position, we should decrease the maximum among the set of $\left\{\left|a_{B}-a_{B j} a_{j}\right|, \mid w_{j}-a_{j w} w_{w}\right.$ $\mid\}$, and the problem can be expressed as follows.

Min-max $\left\{\left|w_{B}-a_{B j w_{j}}\right|,\left|w_{j}-a_{j w} w_{w}\right|\right\}$

Subject to

$\sum_{\mathrm{j}} \mathrm{W}_{\mathrm{j}=1(1)}$

$\mathrm{W}_{\mathrm{j} \geq 0 \text {,for all } \mathrm{j}}$

Problem Eq. (1) can be shifted to the following linear programming problems:

Min $\xi^{L}$

Subject to

$\left|w_{B}-a_{B j w_{j}}\right| \leq \xi^{L}$, for all $\mathrm{j}$

$\left|w_{j}-a_{j w} w_{w}\right| \leq \xi^{L}$, for all $\mathrm{j}$

$\sum_{i=1(2)}$

$w_{j} \geq 0$, for all $j$

After resolving the problem Equation (2), the optimum weights $\left(w_{1}^{*}, w_{2}^{*}, w_{3}^{*}, \ldots \ldots, w_{n}^{*}\right)$ and $\xi_{L}^{*}$ are attained. $\xi_{L}^{*}$ can be perceived as a direct indicator of the evaluation system's reliability. The nearer the value of $\xi_{L}^{*}$ is to Zero (0), the higher the reliability, and accordingly, the more consistent the evaluations become.

\section{Application in Real-world}

\subsection{Social Sustainability in Pakistan}

Currently, the global economy has been pushing to draw concentration on long-term sustainability development due to high increase in demand for energy, water, and mineral resources. In most of the conditions, the main concentration has been on the stability of the economy. Nevertheless, the sustainability of environment and social sector have the main influence on economy-related decision and policies that have a constructive and long-lasting economic effect. Pakistan is an emerging economy in South Asia. The country is still in its early phases in case of sustainability (Ahmad et al., 2019). From the past years, it has been an intense devotion to non-economic facets of growth in sustainability. In order to move sustainable development, many policies and guiding principles have been developed in Pakistan, but like various other developing nations, it has not been successful until now in its initiatives. The reasons behind this factor may consist of lacking enforcement of regulatory policies on the government part and lacking of commitment at higher level of management to implement those measures on the side of corporations which lead to emphasize further on sustainability of economy. As an outcome, social activities have insert pressure at national as well as international level which has enforced the Pakistani manufacturing corporations to evaluate scientifically their direct and indirect social liability (Kapitan and Ikram, 2019). Investigation by Moroke et al. (2019); Mani et al. (2016) demonstrates that social issues have been predominantly challenging in emerging economies, so they need to conduct more in-depth research on the issue of social sustainability (Cerri, Thøgersen and Testa, 2019). This study is the initial step towards addressing the various severe negative impacts of manufacturing companies' supply chain processes on society in developing countries. So, this study is one of few conducted to examine social sustainability specifically in Pakistan.

In order to achieve applicability and usability of proposed framework and to provide inclusive assessment of social sustainability, a total sample of 53 practitioners of Pakistani manufacturing companies has been selected in diverse as chemical, electric and electronics, cement, telecom, tiles, automotive and motorcycle manufacturing companies with over more than 10 years of working experience. Total of 20 supply chain manager, 15 general managers, 3 finance managers, 15 assistant supply chain managers has participated in this study. Data has been gathered by conducting interviews and discussion with practitioners after enlightening them the motive of the study.

\subsection{BWM Application}

\subsubsection{Decision Criteria Determination}

First and foremost step is the identification of a set of criteria. The criterion was chosen after combining the review of literature and input from practitioners and decision-makers from manufacturing industry. At initial stage, above mentioned 24 social sustainability criteria were introduced to experts of their field for the purpose to evaluate at alternative times, as shown in table 2 . They had also provided the guidelines how to fill out the questionnaire. Practitioners were asked to select 1 for more relevant criteria to their operations and 0 for irrelevant criteria. The experts in their professions were requested to mention other appropriate criteria according to their experience that may enhance the corporations' social sustainability in specific and organizational overall sustainability in broad. The researcher concurred with practitioners that criteria which are appropriate by minimum of 45 experts would be incorporated in 2 nd review round. Two more criteria were proposed by two experts. Overall total of three interview rounds were conducted to improve the criteria set. Eventually, eleven social sustainability criteria were carefully chosen mentioned in table 3 . 
Table 3. Sorted out criteria for evaluation.

\begin{tabular}{|c|c|c|}
\hline \# & $\begin{array}{l}\text { Social Sustainability } \\
\text { Criterion }\end{array}$ & Description \\
\hline 1 & $\begin{array}{l}\text { Community education \& } \\
\text { training Influence (SSC1) }\end{array}$ & $\begin{array}{l}\text { This criterion contemplates the impact and transfer of knowledge from the employer to } \\
\text { its employees and community in which they run their operations }\end{array}$ \\
\hline 2 & Cultural values (SSC2) & It relates to the preservations of society's intangible benefits of culture \\
\hline 3 & $\begin{array}{l}\text { Employment practices } \\
\text { (SSC3) }\end{array}$ & This criterion observes the methods and programs relating to employees. \\
\hline 4 & $\begin{array}{l}\text { Health and Safety Practices } \\
\text { at work (SSC4) }\end{array}$ & $\begin{array}{l}\text { This criteria contemplates to both the Firm's focus on their operations and as well as } \\
\text { on potential supplier operations of the Health and safety practices }\end{array}$ \\
\hline 5 & $\begin{array}{l}\text { Influence of contractual } \\
\text { stakeholders (SSC5) }\end{array}$ & $\begin{array}{l}\text { This criterion focuses on the attention of the potential suppliers who can insert force to } \\
\text { their stakeholders involve to get incorporated into their operations }\end{array}$ \\
\hline 6 & $\begin{array}{l}\text { Information disclosure } \\
\text { (SSC6) }\end{array}$ & $\begin{array}{l}\text { This criterion involves the firms disseminating the information to their customers and } \\
\text { other stakeholders relating to the material used and procedures employed during man- } \\
\text { ufacturing processes and discharge of carbon. }\end{array}$ \\
\hline 7 & $\begin{array}{l}\text { Mobility and accessibility } \\
\text { (SSC7) }\end{array}$ & $\begin{array}{l}\text { It relates to adequate access to transportation services, various ways of non-motored } \\
\text { mobility and or easy approach to nearby public services. }\end{array}$ \\
\hline 8 & $\begin{array}{l}\text { Occupational Health and } \\
\text { Safety management system } \\
\text { (SSC8) }\end{array}$ & It includes the welfare and health \& safety of workers at work. \\
\hline 9 & $\begin{array}{l}\text { Research development and } \\
\text { innovation (SSC9) }\end{array}$ & $\begin{array}{l}\text { It comprises of technology development in infrastructure and innovation in processes } \\
\text { to serve society in a better way. }\end{array}$ \\
\hline 10 & $\begin{array}{l}\text { Employees' rights \& inter- } \\
\text { ests (SSC10) }\end{array}$ & $\begin{array}{l}\text { This criterion considers the sustainable employment issues and with the factors that } \\
\text { promote employee concerns. }\end{array}$ \\
\hline 11 & $\begin{array}{l}\text { Stakeholders } \quad \text { rights } \\
\text { (SSC11) }\end{array}$ & $\begin{array}{l}\text { This criterion is related to society which has an interest in business and affected directly } \\
\text { or indirectly by the operations of business. }\end{array}$ \\
\hline
\end{tabular}

\subsubsection{Identification of the Best and Worst Criteria} All of the respondents in the second phase specified the most significant and the less meaningful social sustainability criteria, as the best and worst criteria by exercising a questionnaire. The results regarding the best and worst criteria are described in table 3 .

\subsubsection{Finding the Preference of Best Criteria over Others Criteria}

In the 3 rd phase, the responders were requested to identify the best criteria preference among other criteria by employing 1-9 measurement instruments. Table 5 is showing the feedback of one of responders.

\subsubsection{Detecting the Other Criterion Preference over the Worst Criterion}

In the next step, the responders were requested to identify the preference ratio of altogether criteria over the less significant criteria by through questionnaire, this time also using the measurement instrument of 1-9. Table 6 is also depicting the feedback of one of respondents.

\subsubsection{Finding out the Optimal Weights of Criteria} In the final step, by resolving the BWM model for all of the 53 responders, the optimum weights of the criteria are computed. At next step, a simple weighted average for every criterion is calculated to get a single weight vector, and a simple weighted average as showing is table 7 . Hereafter, the judgments are more uniform and highly reliable. In addition, the standard deviation (s.d.) for every criterion is shown in Table 7. Smaller numbers in standard deviation is depicting the consistency and uniformity among responders.

\section{Results and Discussion}

Table 6 is showing* the final results of this study. The provided results demonstrate the understanding of managerial decisions strategically. According to table 3, the Employment practices (SSC3) has the maximum weight 0.291 of social sustainability criteria. Employment practices are much more significant criteria for the organization when they endeavour to attain social sustainability specifically and overall organizational sustainability in extensive. It is succeeded by Community education \& training Influence (SSC1) with criterion weight of 0.120 . The next criterion weight is 0.118 which represents the Employees' rights \& interests (SSC10). In order to improve the social sustainability in particular and overall sustainable development in general, it is the dire need to keep into consideration and need the serious attention on the Employment practices by the practitioners and decision-makers especially in manufacturing sector of developing countries. After the criteria on Employment practices has been established and executed, it will create the base for insertion and industrialized the other criteria, guiding to upgrading the whole program. These results further propose that if manufacturing concerns want to set up and enhance the social sustainability in their organizations, they must strategically focus and promote the influence of Employment practices by consorting with potential workers. It may strengthen the proficiencies and program competencies; create the ground 
Table 4. Best and Worst criteria determined by experts 1-53.

\begin{tabular}{|l|l|l|}
\hline Social sustainability criteria (SSC) & Experts Extracted as Best & Experts Extracted as Worst \\
\hline Community education \& training Influence (SSC1) & $2,10,13,17,25$ & $22,26,36$ \\
\hline Cultural values (SSC2) & $6,20,31,38$ & $8,12,14,16,34$ \\
\hline Employment practices (SSC3) & $8,16,20,27,30,31$ & 28 \\
\hline Health and safety Practices at work (SSC4) & $5,18,22,24,31$ & $16,31,35,18,21,32,34,22$ \\
\hline Influence of contractual stakeholders (SSC5) & $2,6,18,31$ & $11,28,33,37$ \\
\hline Information disclosure (SSC6) & 11,18 & $1,5,22,27,24,38$ \\
\hline Mobility and accessibility (SSC7) & $13,27,25,21,33$ & $4,8,11,17,18$ \\
\hline Occupational Health and Safety management system (SSC8) & $4,16,19,23,39$ & $2,9,13,29$ \\
\hline Research development and innovation (SSC9) & $5,17,18,22,38$ & $3,10,14,30$ \\
\hline Employees' rights \& interests (SSC10) & $6,18,19,23,39$ & $4,11,14,31$ \\
\hline Stakeholders rights (SSC11) & $7,15,31$ & $6,14,20$ \\
\hline
\end{tabular}

Table 5. For expert 1, Best Criteria Preference over the other Criteria.

\begin{tabular}{|l|c|c|c|c|c|c|c|c|c|c|c|}
\hline Social sustainability Criteria & SSC & SSC & SSC & SSC & SSC & SSC & SSC & SSC & SSC & SSC & SSC \\
(SSC) & $\mathbf{1}$ & $\mathbf{2}$ & $\mathbf{3}$ & $\mathbf{4}$ & $\mathbf{5}$ & $\mathbf{6}$ & $\mathbf{7}$ & $\mathbf{8}$ & $\mathbf{9}$ & $\mathbf{1 0}$ & $\mathbf{1 1}$ \\
\hline Most important SSC1 & 1 & 4 & 5 & 7 & 5 & 9 & 5 & 7 & 5 & 3 & 5 \\
\hline
\end{tabular}

Table 6. For the expert 1, Preference of all Criteria over the Worst Criteria.

\begin{tabular}{|l|c|c|c|c|c|c|c|c|c|c|c|}
\hline Criteria & SSC & SSC & SSC & SSC & SSC & SSC & SSC & SSC & SSC & SSC & SSC \\
& $\mathbf{1}$ & $\mathbf{2}$ & $\mathbf{3}$ & $\mathbf{4}$ & $\mathbf{5}$ & $\mathbf{6}$ & $\mathbf{7}$ & $\mathbf{8}$ & $\mathbf{9}$ & $\mathbf{1 0}$ & $\mathbf{1 1}$ \\
\hline Least important criterion SSC & 9 & 6 & 5 & 3 & 5 & 1 & 5 & 3 & 5 & 7 & 5 \\
\hline
\end{tabular}

Table 7. The BWM Results: For criteria weights of respondents.

\begin{tabular}{|c|c|c|}
\hline Criteria & Average Weight & Standard Coefficient \\
\hline Community education \& training Influence (SSC1) & 0.120 & 0.019 \\
\hline Cultural values (SSC2) & 0.010 & 0.022 \\
\hline Employment practices (SSC3) & 0.291 & 0.030 \\
\hline Health and Safety Practices at work (SSC4) & 0.034 & 0.010 \\
\hline Influence of contractual stakeholders (SSC5) & 0.107 & 0.034 \\
\hline Information disclosure (SSC6) & 0.102 & 0.030 \\
\hline Mobility and accessibility (SSC7) & 0.0368 & 0.040 \\
\hline Occupational Health and Safety management system (SSC8) & 0.120 & 0.029 \\
\hline Research development and innovation (SSC9) & 0.046 & 0.035 \\
\hline Employees' rights \& interests (SSC10) & 0.118 & 0.032 \\
\hline Stakeholders rights (SSC11) & 0.0272 & 0.021 \\
\hline
\end{tabular}

for other criteria to be executed and initiate some innovations in operations.

In order to reduce the hostile social effects of manufacturing processes and to enhance the social sustainability, monitoring these actions would be a substantial step that should be taken, according to $\mathrm{Xu}$ et al. (2019), Dendena and Corsi (2015). Further, Research development and innovation (SSC9) scored the value 0.108 and stands at 4 rth position in criterion selection process. The consequence of this outcome is that production industries need to focus and execute the Research development and innovation (SSC9) after pondering and establishing the most significant criteria SSC3, SSC1 and SSC10 respectively to attain social sustainability in the supply chain. While Influence of contractual stakeholders (SSC5) having the weighted average value 0.107 and stands at fifth positions according to weighted average value. SSC7, SSC11 and SSC9 having weighted average score $0.368,0.272$ and 0.46 are positioned at 7 th, 8th and 9th rank correspondingly.

Health and Safety Practices at work (SSC4) has a weighted average score of 0.034 . which stands at 10 th position. It is surprising having such result, It is uncertain why the responders evaluated this criterion as less significant. One of the reasons it may be is that manufacturing concerns in Pakistan do less invests on wellbeing of employees and workers' health related matters. It may be possible that they have already developed highly graded criterion, which means that there is need to draw attention to less flourished criteria. For more effective, it also indicates that occupational health \& safety management system is further suitable for production industry in Pakistan and organizations in other emerging economies which are facing labour market instability, to assist them by managing sustainability in their operations related to supply chain. Therefore, it is showing that the production industry in Pakistan is quite in its beginning stage when the matter comes for the applicability of social sustainability, meanwhile the concentration and the highest possibilities originate from more basic initiatives related to partnering. It is, hence, further research needed to confirm the results. Social sustainability criteria SSC2 as Cultural values is categorized at 11 th position with weighted average score 0.010 which is least significant in criterion selection process. 
The outcomes of this research are contradictory to past studies on social sustainability criteria. For instance, previous reviews by Azadnia et al. (2015); Carvalho, Domingues and Sampaio (2019); Crane et al. (2019) have ranked the Occupational Health and Safety management system at highest position, but in this study it has been ranked at 2nd lowest position. The outcomes of earlier studies are not surprising, as the comfort and security of the employees, who are the most significant assets of any organization, and the matter is to achieve viable development. In another study conducted by Badri Ahmadi et al. (2017), Employment practices was ranked at lowest position in social sustainability criteria. That study was conducted in telecom industry to select sustainable supplier. But in this study, the Employment practices is ranked at highest position which is contradicted with previously mentioned study however the outcome of this study related to Employment practices is matched with the study conducted by Kusi-Sarpong, Gupta and Sarkis (2019). Similarly, stakeholders' rights were ranked high in study conducted by Ahmadi, Kusi-Sarpong and Rezaei (2017), but in this study this criterion stands at lower average position. Due to rare empirical studies one the basis of which we could base our findings, it is the fact that studies on social sustainability in supply is in its infancy stage. It all depends upon managers/practitioners, which criteria they have to prioritize and focus and which social criteria they have to defer. Nonetheless, the ultimate goal and viability of the programs involved may help practitioners to choose and apply specific social sustainability criteria in supply chain.

\section{Conclusion and Recommendations for $\mathrm{Fu}$ - ture Research}

The manufacturing concerns, due to their operations, have an immense negative impact on global environment and society by throwing their pollution and other chemical hazards in open-air, particularly in emerging economies like Pakistan. To deal with these issues, a number of manufacturing concerns have taken many initiatives. Moreover, several studies have addressed the sustainability broadly, but those studies have not focused specifically on social sustainability in supply chain. Only few studies incorporated the social sustainability dimensions in their SSCM models, and they only concentrated on some facets of supply chains.

The established frameworks in diverse and isolated forms do not support when capabilities and the resources required to handle the social influence of manufacturing concerns to attain sustainable operations systematically and comprehensively matters. Assimilation of these various models in one comprehensive model to support manufacturing sector incorporating the social sustainability in supply chains does presently not exist. In order to overcome this situation; this study has been started by reviewing the existing literature related to sustainability in supply chains to find out the potential criteria within the manufacturing sector; various reviews were conducted by experts to identify and recommend a comprehensive model.

According to results, the most important criteria is Employment practices and least important criteria is cultural values, while health \& safety practices has been ranked at 2nd least important criteria, which need to be re-tested again in order to the explore the reasons. A suggested model can be helpful to enhance organizational capability needed to develop corporate sustainability. Mainly, the model can assist supply chain practitioners to compute the effect of social sustainability in manufacturing concerns more effectively.

There are many limitations in this research; therefore further research is obligatory. These limitations provide the foundation for the further improvement in this specific area of study. The main and first one limitation is that this research is of exploratory in nature and comprises of only manufacturing sector, so it is difficult to generalize the findings. More deep analysis is needed to open new insights into social sustainability in supply chains. Other manufacturing or services sectors may also be taken into consideration for broader implication. This is a cross-sectional study and covers a single period of time. Longitudinal study may also be recommended to check whether the criteria may modify over time due to priority changes according to the need of the organizations. It is also recommended to use other MCDM frameworks along with additional model of social sustainability to compute weighted average scores and match them with the BWM results of this study. It may be clear that further research is required on social sustainability in emerging economies.

\section{Funding Acknowledgement}

We highly praise the honorable Professor Hou Yumei for her valuable guidance and great support in this research. This research was supported and funded by the project Joint Opyimization of OmniChannel Retailer Procurement and Pricing Considering Consumer Behavior (G2019203387) under the umbrella of Hebei Province Natural Science Foundation Project in 2019.

\section{References}

1. Aboutorab H., Saberi M., Asadabadi MR., Hussain O., Chang E., 2018, ZBWM: The Z-number extension of Best Worst Method and its application for supplier development, in: Expert Systems with Applications, 107, p. 115-125.

2. Ahi P., SEARCy C., Jaber MY., 2018, A Quantitative Approach for Assessing Sustainability Performance of Corporations, in: Ecological Economics, 152, p. 336-346.

3. AHMAD, S., WONG, K. Y., \& RAJOO, S., 2019, Sustainability indicators for manufacturing sectors: A 
literature survey and maturity analysis from the triple-bottom line perspective, in: Journal of Manufacturing Technology Management, 30(2), p. 312-334.

4. ARCESE G., LuCChetTI MC., MASSA I., 2017, Modeling Social Life Cycle Assessment framework for the Italian wine sector, in: Journal of Cleaner Production, 140, p. 1027-1036.

5. Azevedo SG., Carvalho H., Duarte S., CruzMACHADO V., 2012, Influence of Green and Lean Upstream Supply Chain Management Practices on Business Sustainability, in: IEEE Transactions on Engineering Management, 59(4), p. 753-765.

6. Badri Ahmadi H., Kusi-Sarpong S., Rezaei J., 2017, Assessing the social sustainability of supply chains using Best Worst Method, in: Resources Conservsation and Recycling, 126, p. 99-106.

7. Brandenburg M., Seuring S., 2014, Quantitative models for sustainable supply chain management: Developments and directions, in: European Journal of Operational Research, 233(2), p. 299-312.

8. Cerri J., Thøgersen J., Testa F., 2019, Social desirability and sustainable food research: A systematic literature review, in: Food Quality and Preference,71, p. 136-140.

9. Ciliberti F., Pontrandolfo P., Scozzi B., 2008, Investigating corporate social responsibility in supply chains: a SME perspective, in: Journal of Cleaner Production, 16(15), p. 1579-1588.

10. Closs DJ., Speier C., Meacham N., 2011, Sustainability to support end-to-end value chains: the role of supply chain management, in: Journal of the Academy of Marketing Science, 39(1), p. 101-116.

11. DAS D., 2017, Development and validation of a scale for measuring Sustainable Supply Chain Management practices and performance, in: Journal of Cleaner Production, 164, p. 1344-1362.

12. Dias LS., IERAPETRITOU MG, 2017, From process control to supply chain management: An overview of integrated decision making strategies, in: Compueters and Chemical Engineering, 106, p. 826-835.

13. EPSTEIN, M. J., 2018, Making sustainability work: Best practices in managing and measuring corporate social, environmental and economic impacts, Routledge.

14. Font X., Tapper R., Schwartz K., Kornilaki M., 2008, Sustainable supply chain management in tourism, in: Business Strategy and the Environment, 17(4), p. 260-271.

15. Galal NM., Moneim AFA., 2016, Developing Sustainable Supply Chains in Developing Countries, in: Procedia CIRP, 48, p. 419-424.

16. Govindan K., 2018, Sustainable consumption and production in the food supply chain: A conceptual framework, in: International Journal of Production Economics, 195, p. 419-431.

17. Hale J., Legun K., Campbell H., Carolan M., 2019, Social sustainability indicators as performance, in: Geoforum, 103, p. 47-55.

18. Huo B., Gu M., WANG Z., 2019, Green or lean? A supply chain approach to sustainable performance, in: Journal of Cleaner Production, 216, p. 152-166.

19. Hussain M., Ajmal MM., Gunasekaran A., Khan M., 2018, Exploration of social sustainability in healthcare supply chain, in: Journal of Cleaner Production, 203, p. 977-989.

20. Interlenghi SF.,De Almeida Bruno P., Araujo O DE QF,DE MedeIRos JL, 2017, Social and environmental impacts of replacing transesterification agent in soybean biodiesel production: Multicriteria and principal component analyses, in: Journal of Cleaner Production, 168, p. 149-162.

21. Jia F., Gong Y., Brown S, 2018, Multi-tier sustainable supply chain management: The role of supply chain leadership, in: International Journal of Production Economics, p. 5-58.

22. KAPITAN, V., S., \& IKRAM, S., 2019, The Influence of Profitability and Leverage on Corporate Social Responsibility Disclosure, in: Journal of Accounting Auditing and Business, 2(2), p. 14-25.

23. KORNUTA, J. A., NEPIYUSHCHIKH, Z., GASHEVA, O. Y., MUKHERJEE, A., ZAWIEJA, D. C., \& DIXON, J. B., 2015, Effects of dynamic shear and transmural pressure on wall shear stress sensitivity in collecting lymphatic vessels, in: American Journal of Physiology-Regulatory, Integrative and Comparative Physiology, 309(9), p. 1122-1134.

24. Kleindorfer PR., Singhal K., Wassenhove LN., 2009, Sustainable Operations Management, in: Production and Operations Management, 14(4), p. 482-492.

25. KUMAR, A., \& ANBANANDAM, R., 2019, Development of social sustainability index for freight transportation system, in: Journal of cleaner production, 210, p. 77-92.

26. MANZINI, R., ACCORSI, R., AYYAD, Z., BENDINI, A., BORTOLINI, M., GAMBERI, M., \& GALLINA TOSCHI, T., 2014, Sustainability and quality in the food supply chain. A case study of shipment of edible oils, in: British Food Journal, 116(12), p. 2069-2090.

27. MAXwell D., VAN DER Vorst R., 2003, Developing sustainable products and services, in: Journal of Cleaner Production, 11(8), p. 883-895.

28. MartínEZ-JuRAdo PJ., MoYANO-FuENTES J., 2014, Lean Management, Supply Chain Management and Sustainability: A Literature Review, in: Journal of Cleaner Production, 85, p. 134-150.

29. Manavalan E., Jayakrishna K., 2019, A review of Internet of Things (IoT) embedded sustainable supply chain for industry 4.0 requirements, in: Computer and Industrial Engineering, 127, p. 925-953.

30. Mi X., TANG M., Liao H, Shen W., Lev B, 2019, The state-of-the-art survey on integrations and applications of the best worst method in decision making: Why, what, what for and what's next?, in: Omega.

31. Moroke T., Schoeman C., Schoeman I., 2019, Developing a neighbourhood sustainability assessment model: An approach to sustainable urban development, in: Sustainable Cities and Society, p. 101433.

32. NawaZ W., Linke P., Koç M., 2019, Safety and sustainability nexus: A review and appraisal, in: Journal of Cleaner Production, 216, p. 74-87.

33. Nishat Faisal M., 2010, Sustainable supply chains: a study of interaction among the enablers, in: Business Process Management Journal, 16(3), p. 508-529.

34. OGASAWARA, K., \& YUMITORI, M., 2019, Early-life exposure to weather shocks and child height: Evidence from industrializing Japan, in: SSMpopulation health, 7, 100317.

35. Oruezabala G., Rico J-C., 2012, The impact of sustainable public procurement on supplier 
management - The case of French public hospitals, in:Industrial Marketing Management, 41(4), p. 573580.

36. O'Rourke D., 2014, The science of sustainable supply chains., in: Science, 344(6188), p. 1124-1127.

37. Rachih H., Mhada FZ., Chineb R., 2019, Metaheuristics for reverse logistics: A literature review and perspectives, in: Computer and Industrial Engineering, 127, p. 45-62.

38. RAJAK S.,VInOdH S., 2015, Application of fuzzy logic for social sustainability performance evaluation: a case study of an Indian automotive component manufacturing organization, in: Journal of Cleaner Production, 108, p. 1184-1192.

39. RAmezankHani MJ., ToRabi SA., VAhidi F., 2018, Supply chain performance measurement and evaluation: A mixed sustainability and resilience approach, in: Computers \& Industrial Engineering, 126, p. 531-548.

40. Rezaei J., Hemmes A., Tavasszy L., 2017, Multicriteria decision-making for complex bundling configurations in surface transportation of air freight, in: Journal of Air Transport Management, 61, p. 95105.

41. Rezaei J., Nispeling T., Sarkis J., Tavasszy L., 2016, A supplier selection life cycle approach integrating traditional and environmental criteria using the best worst method, in: Journal of Cleaner Production, 135, p. 577-588.

42. Schätter F., HANSEN O., WiEns M., SchultmanN F., 2019, A decision support methodology for a disaster-caused business continuity management, in: Decision Support Systems, 118, p. 10-20.

43. Shibin K.T.,GunaseKaran A., Dubey R, 2017, Explaining sustainable supply chain performance using a total interpretive structural modeling approach, in: Sustainable Production and Consumption, 12, p. 104-118.

44. Soundararajan V., Brammer S., 2018, Developing country sub-supplier responses to social sustainability requirements of intermediaries:
Exploring the influence of framing on fairness perceptions and reciprocity, in: Journal of Operations Management, 58, p. 42-58.

45. Sutherland JW., Richter JS., Hutchins MJ., ET AL., 2016, The role of manufacturing in affecting the social dimension of sustainability, in: CIRP Annals, 65(2), p. 689-712.

46. Spence LJ., RinAldi L., 2014, Governmentality in accounting and accountability: A case study of embedding sustainability in a supply chain, in: Accounting, Organizations and Society, 39(6), p. 433-452.

47. Sierra LA.,Yepes V., Pellicer E., 2018, A review of multi-criteria assessment of the social sustainability of infrastructures, in:Journal of Cleaner Production, 187, p. 496-513.

48. Sigala M., 2008, A supply chain management approach for investigating the role of tour operators on sustainable tourism: the case of TUI, in: Journal Cleaner Production, 16(15), p. 1589-1599.

49. Tost M., Hitch M., Chandurkar V., Moser P., FEIEL S., 2018, The state of environmental sustainability considerations in mining, in: Journal of Cleaner Production, 182, p. 969-977.

50. Wolf J., 2014, The Relationship Between Sustainable Supply Chain Management, Stakeholder Pressure and Corporate Sustainability Performance, in: Journal of Business Ethics, 119(3), p. 317-328.

51. Wang Y., SingGiH M.,WAng J.,Rit M., 2019, Making sense of blockchain technology: How will it transform supply chains?, in: International Journal of Production Economics, 211, p. 221-236.

52. Wan Ahmad WNK, Rezaei J., De Brito MP., TAVASSZY LA., 2016, The influence of external factors on supply chain sustainability goals of the oil and gas industry, in: Resource Policy, 49, p. 302-314.

53. YAWAR, S. A., \& SEURING, S., 2017, Management of social issues in supply chains: a literature review exploring social issues, actions and performance outcomes, in: Journal of Business Ethics, 141(3), p. 621-643. 